\title{
评 述
}

\section{胎盘铁转运蛋白 Zyklopen 研究进展}

\author{
关鹏 ${ }^{(1)}$ ，王娜 ${ }^{(1)}$ ，段相林 ${ }^{(1)}$ ，常彦忠 ${ }^{(1)^{*}}$ \\ (1) 河北师范大学生命科学学院分子铁代谢研究室, 石家庄 050016; \\ (2) 河北医科大学基础课部, 石家庄 050091 \\ * 联系人, E-mail: chang7676@163.com
}

收稿日期: 2011-06-08; 接受日期: 2011-08-08

国家自然科学基金(批准号: 10979025, 30930036)资助项目

doi: 10.1360/052011-380

摘要 Zyklopen (ZP) 作为铜蓝蛋白的同系物, 是近年来发现的铁转运蛋白. ZP 具有一个位 于羧基末端的跨膜结构域，在胎盘大量表达，也分布于脑、肾、视网膜、乳腺、睪丸等组织， 但目前还不清楚 ZP 在这些组织中的功能. ZP 具有亚铁氧化酶的活性, 细胞内缺铜会引起 $\mathrm{ZP}$ 蛋白表达减少. 在胎盘中, $\mathrm{ZP}$ 可能通过将二价铁离子氧化为三价铁离子, 帮助三价铁与 胎儿循环系统中的转铁蛋白相结合, 从而参与铁从母体到胎儿的转运过程.

关键词

胎盘

铁

亚铁氧化酶

胎盘铁转运蛋白
铁是生物体内一种必需的营养元素. 胎儿在母 体子宫内快速生长, 每天需要大约 300 400 mg 的铁, 这些铁均由母体通过胎盘运输而来 ${ }^{[1]}$. 胎盘是胎儿和 母体进行物质交换的重要器官, 当母体和胎儿血型 不同时, 胎盘既要隔离不同血型的血液, 还要作为营 养与代谢物质交换的通道, 起到分离膜和通道的作 用. 当母体轻度缺铁, 并不一定导致胎儿严重的发育 障碍, 这与胎盘主动转运铁的功能代偿性增加有关. 通过胎盘的主动转运功能, 铁由母体血浆输送至胎 儿至少需要穿过合体滋养层细胞、基底膜和胎儿血管 内皮细胞等结构, 对此复杂过程迄今尚未全面了解. 目前研究证实, 胎盘中存在一种与铁释放有关的含 铜氧化酶, 这种氧化酶结构与血清铜蓝蛋白 (ceruloplasmin, CP) 和膜铁转运辅助蛋白 (hephaestin, $\mathrm{HP})$ 类似, 可能参与了胎盘的铁转运 ${ }^{[2]}$.

\section{Zyklopen 的发现}

怀孕大鼠铜缺乏会造成胎鼠缺铁 ${ }^{[3]}$, 表明铜在胎
盘铁转运的过程中发挥着作用. 2000 年, 英国科学家 Danzeisen 等人 ${ }^{[4]}$ 在人胎盘滋养层细胞系中发现相当 于 $\mathrm{CP}$ 的膜结合蛋白, 该蛋白类似于血浆中的 CP 和 小肠中的 HP. 当时他们并不确定这个蛋白是 CP 或 $\mathrm{HP}$ 的变体还是一种新的蛋白, 因此他们称这种内源 性的 CP 为“胎盘含铜氧化酶”. 公共数据库中有一些 基因组和表达序列与 HP 和 CP 的序列类似, 但不完 全相同. GenBank 将这些新的编码序列命名为 Hephaestin-like 1(Hephl1), 推测编码一种类似 CP 和 HP 的蛋白. 2010 年, Chen 等人 ${ }^{[5]}$ 证实了 Hephll 基因 所编码的蛋白就是 “胎盘含铜氧化酶”, 他们根据希 腊神话中独眼怪 Zyklops 的传说, 将这种新的蛋白命 名为 Zyklopen (ZP). 因为 HP 的命名源自希腊神话中 锻造之神赫淮斯托斯, 传说赫淮斯托斯联合独眼怪 开发丰富的矿山, 专门为诸神锻造精良的器具, 所以 这一命名也反映了 ZP 和 HP 的密切关系.

\section{Zyklopen 的结构及表达分布}

Zyklopen 是一种含铜的亚铁氧化酶, 与 $\mathrm{CP}$ 和 
$\mathrm{HP}$ 属同一家族, 在结构上与 $\mathrm{CP}$ 和 $\mathrm{HP}$ 相似 ${ }^{[6]} . \mathrm{ZP}$ 的 基因与 $\mathrm{CP}$ 和 $\mathrm{HP}$ 基因序列高度一致，小鼠 $\mathrm{ZP}$ 与 $\mathrm{CP}$ 有 $56 \%$ 的一致性, 与 $\mathrm{HP}$ 有 $59.4 \%$ 的一致性. 在蛋白 水平, $\mathrm{ZP}$ 与 $\mathrm{CP}$ 有 $45.9 \%$ 的一致性, 与 $\mathrm{HP}$ 有 $48.8 \%$ 的 一致性. CP, HP 上 I, II, III型铜结合位点以及形成 二硫键的所有半胱氨酸残基都存在于 $\mathrm{ZP}$ 上. Chen 等 人 $^{[5]}$ 根据 ZP 的分子模型发现了 $\mathrm{ZP}$ 与 $\mathrm{CP}$ 和 $\mathrm{HP}$ 的相 似性. ZP 由 6 个杆状花青式形区域(plastocyanin-type domains)组成, 含有 6 个铜原子, 其中 3 个铜原子形 成一个三核簇, 位于 1 区和 6 区的交界面上, 另外 3 个铜原子则以单核形式定位于 $2,4,6$ 区的 I 型铜结 合位点上 ${ }^{[7]}$. 典型的 I 型铜结合位点为扭曲的四面体 或正金字塔型, 由 2 个组氨酸残基和一个半胱氨酸残 基作为铜离子的配基构成一个平面, 由一个较远的 甲硫氨酸残基构成雉体尖端. 由于没有雉体尖端的 甲硫氨酸残基, CP 2 区的 I 型铜结合位点与 4,6 区的 不太相同. 与 $\mathrm{CP}$ 不同, $\mathrm{ZP}$ 和 $\mathrm{HP}$ 的 3 个 I 型铜结合 位点都非常典型. 除了铜结合位点, $\mathrm{ZP}$ 分子上还有一 个特殊的位点, 能特异性地结合 $\mathrm{Fe}^{2+}$, 而 $\mathrm{Fe}^{2+}$ 是铁氧 化酶 $\mathrm{ZP}$ 的底物 ${ }^{[5]}$. 与 $\mathrm{HP}$ 类似, $\mathrm{ZP}$ 蛋白在羧基末端也 包含了一个跨膜结构域, 说明它是一种膜蛋白, 根据 其结构推测 ZP 在细胞外具有与膜铁转运蛋白 (ferriportin, FPN)结合的亚铁氧化酶活性区域.

Chen 等人 ${ }^{[5]}$ 系统地研究了 $C P$ 基因在成年小鼠、 胎鼠和胎盘组织中表达的情况. 他们发现, 在成年小 鼠的脑、肾、睪丸、视网膜等部位都有 ZP 蛋白的表 达, 而在肝脏和小肠内皮细胞没有检测到阳性信号. 免疫组化实验证实, 在小鼠胚胎的脑、膀胱、眼和棕 色脂肪等处有 $\mathrm{ZP}$ 的表达. 在 $\mathrm{ZP}$ 高表达的胎盘中, 胎 盘的血管迷路、卵黄囊和海绵滋养层细胞均有较强的 阳性信号. 值得注意的是, 在脑、肾、眼和胎盘同时 有 $\mathrm{ZP}$ 和 $\mathrm{HP}$ 的表达, 在眼和脑同时有 $\mathrm{ZP}, \mathrm{CP}$ 和 $\mathrm{HP}$ 的表达 ${ }^{[8 \sim 10]}$.

\section{Zyklopen 的功能}

多铜亚铁氧化酶对于所有生命体的铁营养和稳 态都至关重要. 已知的 2 种多铜亚铁氧化酶 $\mathrm{CP}$ 和 HP 在多种组织内辅助完成铁转运 ${ }^{[1]}$. 它们能将二价铁 氧化成三价铁, 三价铁随后被转铁蛋白运走. 在该反 应过程中, 来源于二价铁的电子从多铜亚铁氧化酶 的第 I 结合位点转移到第 II, III结合位点, 在第 II,
III结合位点氧分子被还原成水. 在没有多铜氧化酶 的情况下，一些细胞内的二价铁释放蛋白会降解，从 而引起细胞铁释放减少. 尽管目前关于 ZP 功能的研 究还很少, 但参考同一家族 $\mathrm{CP}$ 和 HP 的功能以及已 知的一些现象, 推测 ZP 在胎盘铁转运的过程中起重 要作用. Andersen 等人 ${ }^{[12]}$ 发现, 大鼠怀孕期间铜缺乏 与胎鼠的铁缺乏相关, 推测是由含铜亚铁氧化酶功 能异常所致. Chen 等人 ${ }^{[5]}$ 发现, 用铜螯合剂处理人胎 盘滋养层细胞系 BeWo 会引起 ZP 表达显著降低, 表 明 ZP 的形成和蛋白结构的稳定需要足够的铜.

胎儿在母体子宫内的快速生长需要大量铁. Gambling 等人 ${ }^{[13]}$ 发现，母体缺铁会引起母体肝脏铁含 量降低, 而胎盘铁含量减低的幅度较小, 胎儿肝脏铁 含量降低的幅度更小。该过程中，胎盘的铁转运发挥 着非常关键的作用. 铁通过胎盘由母体输送到胎儿至 少需要穿过合体滋养层细胞、基底膜和胎儿血管内皮 细胞等结构, 是一种逆浓度主动转运过程, 需要众多 铁转运蛋白参与 ${ }^{[14,15]}$. 目前已证实转铁蛋白(Ferritin) 定位于合体滋养层细胞和毛细血管内皮细胞 ${ }^{[16]}$, 铁蛋 白受体(transferrin receptor, TfR)定位在胎盘的微线毛 膜上 ${ }^{[17]}$, 二价离子转运体 1(divalent metal transporter 1, DMT1)主要表达于胞浆内后期的内吞小体上 ${ }^{[18]}$, 遗传 性血色素病蛋白(hereditary hemochromatosis protein, HFE) 表达在胎盘合体滋养层细胞的顶膜 ${ }^{[19]}$, 膜铁转 运蛋白(ferroportin, FPN)主要表达在胎盘合体滋养层 细胞的胎儿侧 ${ }^{[20]}$. 建立在前人有关胎盘转运铁的机 理 ${ }^{[16]}$ 和 ZP 亚铁氧化酶特性 ${ }^{[6]}$ 的基础上，提出了 ZP 在 胎盘中参与转运铁工作模型(图 1). 胎盘滋养层微线 毛膜 TfR 介导的内吞作用可将结合铁的转铁蛋白摄 入细胞内, HFE 可与 TfR 形成复合物, 负性调节胎盘 合体滋养层细胞摄铁. 但母体的转铁蛋白并不进入 合体滋养层细胞胞浆和胎儿循环中, 而是在入胞后 即释放出所结合铁, 之后本身返回细胞表面, 反复行 使其转运功能 ${ }^{[15,21]}$. 参考肠道铁蛋白释放铁离子的 机制，推测胞浆中的 DMT1 与内吞小体膜相结合，进 而将铁释放到合体滋养层细胞中 ${ }^{[18]}$. 合体滋养层细 胞中的铁蛋白可能同时具有储铁和转运铁的功能, 结合了铁的铁蛋白与基底膜的铁蛋白受体(ferritin receptor, FnR)结合, 释放出铁离子. 释放的铁在 FPN 和 HP/ZP 共同作用下，经毛 细血管内皮细胞以 $\mathrm{Fe}^{3+}$ 的形式释放到胎儿血液循环中 ${ }^{[22]}$. 胎盘中同时有 HP, $\mathrm{ZP}$ 的表达，在铁释放的过程中，究竟 HP, ZP 同时各 


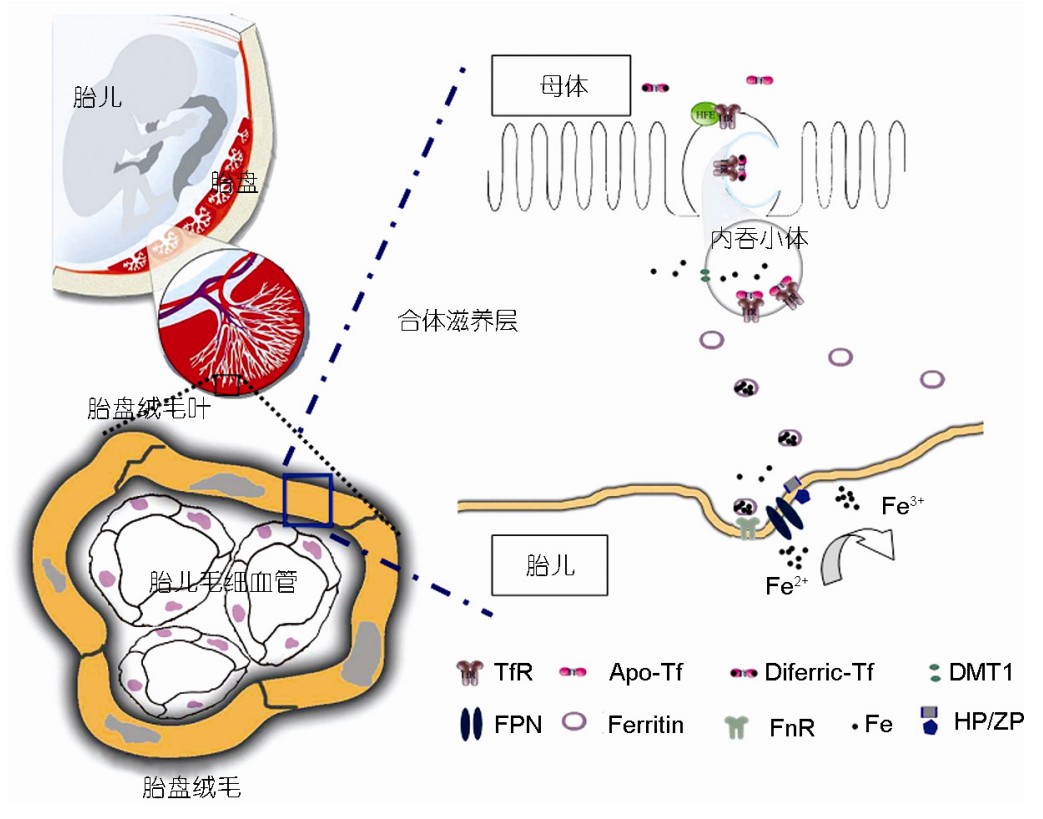

图 1 胎盘铁转运模式图

Apo-Tf: 脱铁转铁蛋白; Diferric-Tf: 结合三价铁的转铁蛋白

自发挥氧化作用还是协同发挥氧化作用还有待进一 步研究.

\section{Zyklopen 的调节}

有关 ZP 调节的研究还不多. ZP 的表达与铁状态 具有正相关性 ${ }^{[2]}$.母体铁缺乏不仅能够增加胎盘 $\mathrm{ZP}$ 的表达, 同时还增加 TfR 和 DMT1 蛋白和 mRNA 的 表达, 表明胎盘对低铁信号非常敏感. 铁反应元件 (iron response element, IRE)/铁调节蛋白(iron regulatory protein, IRP)系统是调节体内铁代谢的重要因素. 许 多铁代谢相关蛋白, 如转铁蛋白、铁蛋白、DMT1、 FPN 等的 mRNA 序列中含有 IRE, 与 IRP有较高的亲 和力. IRP 能感受胞内铁水平, 通过与 IRE 序列结合 或解离, 来调控相关铁代谢蛋白 mRNA 翻译或降解, 而发挥调控胞内铁水平的功能. IRP 有 IRP1, IRP2 两 种形式, IRP1 分布广泛, IRP2 主要分布于脑及小肠. 由于 $\mathrm{ZP}$ mRNA 没有铁反应元件(iron respense elements, IREs), 所以 $\mathrm{ZP}$ 在转录后水平上的调节不受 铁水平的影响. 由于 $\mathrm{ZP}$ 是含铜氧化酶, 具有铜结合 位点, 提示 $\mathrm{ZP}$ 的表达可能受铜调节 ${ }^{[2]}$. 铜缺乏时, $\mathrm{ZP}$ 表达降低, 表明在 ZP 的铜结合位点没有结合铜时,
$\mathrm{ZP}$ 蛋白结构不稳定, 容易被降解; 铜含量增加时, ZP 表达增多, 可能脱辅基的 ZP 是过量表达的, 铜含量 增加会增加具有氧化酶活性的 ZP 增多.

\section{5 研究展望}

ZP 的发现进一步丰富了对机体铁代谢的研究, 同时也提出了新的问题. 如果像本文假设的那样, FPN, ZP 和 HP 将铁释放出合体滋养层细胞, 接下来 铁又是通过什么样的途径穿过内皮细胞进入胎儿的 循环系统? 就吸收铁的过程来看, 胎儿通过胎盘吸 收铁与成人通过小肠吸收铁的过程非常类似, 是否 同样存在相似的调节机制? 既然 CP, HP 和 ZP 属于同 一家族, 具有相似的结构和功能, 它们在组织中单独 表达或同时表达对其功能有何影响? 比如, ZP 和 HP 在胎盘都有表达, 但 $\mathrm{ZP}$ 和 $\mathrm{HP}$ 在胎盘如何协作释 放铁还不清楚. 在视网膜, CP, ZP 和 HP 均有表达, 它 们是各自发挥氧化作用还是作为一个整体发挥作用, 推测 3 种多铜亚铁氧化酶可能具有不同的调节机制, 在不同的条件下分别发挥作用，或者在某些细胞发 挥特定的功能. 这方面的研究不仅可以进一步增加 对铁代谢的认识, 而且对铁代谢异常疾病的治疗具 有广阔的应用前景. 


\section{参考文献}

1 Bothwell T H. Iron requirements in pregnancy and strategies to meet them. Am J Clin Nutr, 2000, 72: S257-S264

2 Danzeisen R, Fosset C, Chariana Z, et al. Placental ceruloplasmin homolog is regulated by iron and copper and is implicated in iron metabolism. Am J Physiol Cell Physiol, 2002, 282: C472-C478

3 Andersen H S, Gambling L, Holtrop G, et al. Effect of dietary copper deficiency on iron metabolism in the pregnant rat. Br J Nutr, 2007, 97: 239-246

4 Danzeisen R, Ponnambalam S, Lea R G, et al. The effect of ceruloplasmin on iron release from placental (BeWo) cells, evidence for an endogenous $\mathrm{Cu}$ oxidase. Placenta, 2000, 21: 805-812

5 Chen H, Attieh Z K, Syed B A, et al. Identification of zyklopen, a new member of the vertebrate multicopper ferroxidase family, and characterization in rodents and human cells. J Nutr, 2010, 140: 1728-1735

6 Prohaska J R. Impact of copper limitation on expression and function of multicopper oxidases(Ferroxidases). Adv Nutr, 2011, 2: 89-95

7 常彦忠, 钱忠明. 铜蓝蛋白与脑铁代谢. 生理科学进展, 2002, 32: 101-105

8 Hahn P, Qian Y, Dentchev T, et al. Disruption of ceruloplasmin and hephaestin in mice causes retinal iron overload and retinal degeneration with features of age-related macular degeneration. Proc Natl Acad Sci USA, 2004, 101: 13850-13855

9 Cui R, Duan X L, Anderson G J, et al. Age-dependent expression of hephaestin in the brain of ceruloplasmin-deficient mice. J Trace Elem Med Biol, 2009, 23: 290-299

10 Petrak J, Vyoral D. Hephaestin-a ferroxidase of cellular iron export. Int J Biochem Cell Biol, 2005, 37: 1173-1178

11 Evans J L, Abraham P A. Anemia, iron storage and ceruloplasmin in copper nutrition in the growing rat. J Nutr, 1973, 103: 196-201

12 Andersen H S, Gambling L, Holtrop G, et al. Effect of dietary copper deficiency on iron metabolism in the pregnant rat. Br J Nutr, 2007, 97: 239-246

13 Gambling L, Charania Z, Hannah L, et al. Effect of iron deficiency on placental cytokine expression and fetal growth in the pregnant rat. Biol Reprod, 2002, 66: 516-523

14 Heaton S J, Eady J J, Parker M L, et al. The use of BeWo cells as an in vitro model for placental iron transport. Am J Physiol Cell Physiol, 2008, 295: C1445-C1453

15 Okuyama T, Tawada T, Furuya H, et al. The role of transferrin and ferritin in the fetal-maternal-placental unit. Am J Obstet Gynecol, 1985, 152: $344-350$

16 Dumartin B, Canivenc R. Placental iron transfer regulation in the haemophagous region of the badger placenta: ultrastructural localization of ferritin in trophoblast and endothelial cells. Anat Embryol(Berl), 1992, 185: 175-179

17 Takami M, Mizumoto K, Kasuya I, et al. Human placental ferritin receptor. Biochim Biophys Acta, 1986, 884: 31-38

18 Gruper Y, Bar J, Bacharach E, et al. Transferrin receptor co-localizes and interacts with the hemochromatosis factor(HFE) and the divalent metal transporter-1(DMT1) in trophoblast cells. J Cell Physiol, 2005, 204: 901-912

19 Parkkila S, Waheed A, Britton R S, et al. Association of the transferrin receptor in human placenta with HFE, the protein defective in hereditary hemochromatosis. Proc Natl Acad Sci USA, 1997, 94: 13198-13202

20 Donovan A, Brownlie A, Zhou Y, et al. Positional cloning of zebrafish ferroportin1 identifies a conserved vertebrate iron exporter. Nature, 2000, 403: 776-781

21 Bastin J, Drakesmith H, Rees M, et al. Localisation of proteins of iron metabolism in the human placenta and liver. Br J Haematol, 2006 , 134: 532-543

22 McArdle H J, Andersen H S, Jones H, et al. Copper and iron transport across the placenta: regulation and interactions. J Neuroendocrinol, 2008, 20: 427-431 


\title{
Zyklopen: a Newly Discovered Multicopper Ferroxidase
}

\author{
GUAN Peng ${ }^{1}$, WANG Na ${ }^{2}$, DUAN XiangLin ${ }^{1} \&$ CHANG YanZhong ${ }^{1}$ \\ 1 Laboratory of Iron Metabolism, College of Life Sciences, Hebei Normal University, Shijiazhuang 050016, China; \\ 2 School of Basic Medicine, Hebei Medical University, Shijiazhuang 050091, China
}

Zyklopen (ZP) is a recently identified ceruloplasmin homologue. ZP is predicted to be tethered to the plasma membrane by its primary sequence. In addition to the placenta, ZP is also present in brain, kidney, retina, mammary gland and testes, but its role in these tissues remains unknown. The protein possessed ferroxidase activity, and protein levels decreased in cellular copper deficiency. In the placenta, ZP is hypothesized to facilitate iron transport from syncytiotrophoblastic cells into the fetal circulation by oxidizing ferrous iron to the ferric form, which is subsequently carried by transferrin.

placenta, iron, ferroxidase, zyklopen

doi: 10.1360/052011-380 